\title{
Does frequent leadership changes influence firm performance? Insights from China
}

\author{
Ahsan Akbar ${ }^{1}$ - Xinfeng Jiang ${ }^{2}$ - Zeeshan Fareed ${ }^{3} \cdot$ Minhas Akbar, $^{4}$ \\ ${ }^{1}$ International Business School, Guangzhou City University of Technology, China \\ ${ }^{2}$ College of Economics and Management, Huazhong Agricultural University, China \\ ${ }^{3}$ School of Economics and Management, Huzhou University, Zhejiang, China \\ ${ }^{4}$ COMSATS University Islamabad, Sahiwal Campus, Pakistan
}

Received: 26 July 2020

Revised: 27 February 2021

Accepted: 5 April 2021

\begin{abstract}
Frequent leadership changes can considerably affect the strategic direction and smooth functioning of an enterprise. However, it still remains unknown that how a frequent leadership change impacts corporate performance indicators. This research aims to investigate the relationship between frequent leadership changes during a year and firm performance. We analyze how CEO frequency during a one-year period impacts performance indicators of Chinese listed firms. The results of panel fixed-effect regression reveal that, CEO turnover leads to a decline in corporate performance measured by ROA and ROE. Moreover, with an increase in annual turnover frequency, the degree of performance decline gets more pronounced. These results remain robust after controlling for endogeneity using the alternate econometric specification of 2SLS. The study findings assert that frequent CEO changes are not conducive to firm performance. Hence, stability in the CEO tenure is essential to sustain and optimize the financial performance of an enterprise.
\end{abstract}

Keywords: leadership change; CEO turnover; firm performance; China JEL Classification Codes: L25, G30

\section{Introduction and theoretical underpinnings}

An essential characteristic of corporations is the separation of ownership and management rights. There is a principal-agent relationship between shareholders and managers, which may lead to agency costs and compromise the interests of shareholders (Jensen and Meckling 1976). Therefore, an efficient corporate governance mechanism is indispensable to ensure that managers work in the best interest of shareholders (Bhagat and Bolton 2008). CEO turnover is a form of corporate governance mechanism which lay off a CEO with diverging interest from the firm's owners.

CEO turnover is a disruptive corporate event for most firms because CEOs are responsible for making important strategic decisions, building organizational structure, and figurehead of the

\footnotetext{
*Corresponding author. E-mail: minhasakbar@cuisahiwal.edu.pk.
}

Citation: Akbar, A., Jiang, X., Fareed, Z., and Akbar, M. (2021) Does frequent leadership changes influence firm performance? Insights from China, Economics and Business Letters, 10(3), 291-298.

DOI: 10.17811/ebl.10.3.2021.291-298 
firm (Kim et al., 2020). Hence, a change in the top leadership can affect corporate culture, processes, and efficiency (Kesner and Sebora 1994; Finkelstein et al. 2009; Quigley and Hambrick 2014). Several theoretical frameworks have been proposed to explain the positive or adverse effects of CEO turnover on corporate performance (Salancik and Pfefer 1980; Boeker 1992; Ballinger and Marcel 2010).

Moreover, enterprise performance is also influenced by various managerial decisions such as short-term financial management (Akbar, 2014), strategic choices over the corporate life cycle (Wang et al. 2020), soundness of corporate governance mechanism (Akbar, 2015) and firms' performance in environmental, social and governance domains (Qureshi et al. 2021; Akbar et al. 2021). Nevertheless, research on CEO turnover and corresponding organizational performance reported mixed results. For instance, some researchers contend that CEO turnover can improve organizational performance as the new CEO can learn from past mistakes, realign its strategic objective, and optimize the firm's operations (Haveman et al. 2001; Shen and Cho 2005).

Contrarily, other researchers claim that CEO turnover may disrupt the internal network and social relations between employees and evoke uncertainty and fear about their job security (Boeker 1992; Ballinger and Marcel 2010; Schepker et al. 2017). Likewise, Chang, Wong, and Paper (2004) reported that forced CEO changes escalate the likelihood of performance deterioration in Chinese State-owned enterprises. Likewise, Firth, Fung, and Rui (2006) pointed out that CEO changes can adversely affect a firm's performance in the stock market. Conyon and $\mathrm{He}$ (2008) contend that the CEO change and consequent poor firm performance is more evident in private Chinese enterprises with the majority shareholders and several independent directors. Likewise, Conyon and $\mathrm{He}$ (2011) found a negative association between CEO change and firm performance in Chinese State-Owned Enterprises (SOEs) and between CEO change and market performance in private enterprises. A meta-analysis of CEO frequency literature also reveals that generally, frequent leadership changes have a negative impact on enterprise performance (Schepker et al. 2017).

Notwithstanding, the existing studies primarily focus on CEO change and do not reflect on how the frequency of CEO turnover affect corporate performance. Pencavel (1972) contemplated that a high turnover of white-collar employees deteriorates firm performance. Similarly, Dalton and Todor (1979) observed the adverse impact of employee turnover on organizational productivity. Besides, they also reported some positive effects when turnover is managed at a low level. Recently, Ferreira and Almeida (2015) revealed a significant negative linkage between employee turnover and sales in Brazilian retail firms.

Nevertheless, the research on how the frequent changes in top leadership during a given time span affects firm performance in that period is yet to be seen. The objective of the present study is to fill this void in the literature. We take Chinese listed firms as a sample and empirically test how a one-time, two-time, three-time, or four-time change in CEO during a one year duration affect the respective firm's profitability performance measured by ROA and ROE.

This study is the first to empirically demonstrate the impact of CEO frequency on the performance of Chinese listed firms. The results of the panel fixed-effect models depict that frequent $\mathrm{CEO}$ changes cause a significant decline in firm performance. Moreover, the decline in corporate performance gets more pronounced with the increase in CEO turnover during one year. 2SLS regression was also carried out as a robustness check, and the principal conclusion remains unchanged.

The subsequent part of the paper is organized as follows: The next section highlights the sample, source of data, and model specification. The third section entails the estimation and robustness of results. Finally, the fourth section concludes this study. 


\section{Sample selection, data source and model construction}

We take 2299 Shanghai and Shenzhen A-share listed firms during 2007-2016 as the study sample. The data source is CSMAR database. The following regression model is constructed to examine the research questions raised in this paper.

$$
\begin{aligned}
\text { Performance } & =\alpha_{0}+\alpha_{1} \text { CEO_C }+\alpha_{2} \text { Log Board size }+\alpha_{3} \text { Log Firm size }+\alpha_{4} \text { Log Firm age } \\
& +\alpha_{5} \text { Sale growth }+\alpha_{6} \text { Ind Dir ed }+\alpha_{7} C E O \text { gender }+\alpha_{8} \text { CEO edu }+\alpha_{9} \text { Lag Dep } \\
& +\sum \text { Year }+\sum \text { Ind }+\varepsilon
\end{aligned}
$$

Firm performance is the dependent variable is commonly measured by ROA and ROE (Akbar, Akbar, and Draz 2021), while CEO_C is the key explanatory variable which is further categorized into four indicators to reflect frequency in CEO turnover. Besides, we control a series of operating and governance-specific firm characteristics in line with the relevant literature. We used the instrumental variables technique of Wooldridge (2010) by employing 2SLS with ivreg2 command to detect the potential endogeneity due to simultaneity and reverse causality in our regression model. We employed lag return on equity (LROE) as an instrument variable because it is plausible to change a CEO on account of sluggish performance in the recent past. The instrumental variable is validated by the "under-identification test of Kleibergen-Paap rk LM". The "Cragg-Donald Wald F statistic" is greater than 10, reflecting the instrument's robustness (Baum, Schaffer, and Stillman 2007). Description of variables is provided in Table 1.

Table 1. Description of variables.

\begin{tabular}{ll}
\hline \hline Variables & Measurement \\
\hline ROA & Ratio of net income to total assets \\
CEO Change & Ratio of net income to total equity \\
& $\begin{array}{l}\text { Dummy Variable, if firm has more than one CEO during the year was } \\
\text { assigned 1, otherwise 0. }\end{array}$ \\
DEO_Chng 1 & $\begin{array}{l}\text { Dummy Variable, if firm has two CEOs during the year was assigned } \\
\text { 1, otherwise 0. (It means firm has changed one CEO during the year) }\end{array}$ \\
DEO_Chng 2 & $\begin{array}{l}\text { Dummy Variable, if firm has three CEOs during the year was assigned } \\
\text { 1, otherwise 0. }\end{array}$ \\
CEO_Chng 3 & $\begin{array}{l}\text { Dummy Variable, if firm has four CEOs during the year then we } \\
\text { assigned 1, otherwise 0. } \\
\text { (Current year sale - previous year sale) / previous year sale }\end{array}$ \\
Sale growth & Log of total assets \\
Log Firm size & Years lapsed since the firm's inception \\
Log board size & Log of number of board of directors \\
Ind Dir Edu (Master & Percentage of number of independent directors holding Master degree \\
\%) & Dummy Variable: Male=1, Female=0 \\
CEO gender & 1=Secondary school, 2=Junior college, 3=Undergraduate, 4=post \\
gEO edu & graduate, 5=Doctoral, 6=other \\
\hline \hline
\end{tabular}

Note: We take CEO gender and CEO edu of first CEO for each firm in a year, if a firm has two or more CEOs.

\section{Empirical analysis}

Table 2 reports the descriptive statistics of variables. The mean value of ROA is 0.051 , the minimum and maximum are -0.172 and 0.21 , respectively, within a range of 0.382 . Likewise, the mean value of ROE is 0.075 with a minimum and maximum of -0.56 and 0.435 , respectively. 
It indicates that Chinese listed companies have fairly good profitability in general. Though, there are considerable differences across sample firms that are worth discussing. Besides, 9.8\% of sample firms report a CEO change in the same year. While $9.4 \%$ of the firms have two CEOs in a year. Whereas the sample percentage of three and four CEOs in one year is $2.4 \%$ and $1.1 \%$, respectively. The results of the control variables are consistent with the prior studies.

Table 2. Summary statistics.

\begin{tabular}{lrrrrrr}
\hline \hline Description & N & Mean & St. Dev & p1 & Median & p99 \\
\hline Performance measures & & & & & & \\
ROA & 20305 & 0.051 & 0.868 & -0.172 & 0.045 & 0.210 \\
ROE & 20467 & 0.075 & 0.692 & -0.56 & 0.077 & 0.435 \\
Leadership measures & & & & & & \\
CEO Change & 20483 & 0.098 & 0.298 & 0 & 0 & 1 \\
CEO_Chng 1 & 20483 & 0.094 & 0.292 & 0 & 0 & 1 \\
CEO_Chng 2 & 20483 & 0.024 & 0.063 & 0 & 0 & 0 \\
CEO_Chng 3 & 20483 & 0.011 & 0.016 & 0 & 0 & 0 \\
Control Variables & & & & & & \\
Sale growth & 19156 & 0.170 & 0.312 & -0.250 & 0.112 & 0.633 \\
Log Firm size & 20483 & 21.959 & 1.483 & 19.276 & 21.736 & 27.080 \\
Log Firm age & 20481 & 2.687 & 0.363 & 1.792 & 2.708 & 3.401 \\
Log board size & 20374 & 2.166 & 0.209 & 1.609 & 2.197 & 2.708 \\
Ind Dir Edu (Master \%) & 20374 & 47.056 & 36.770 & 0 & 44.444 & 91.550 \\
CEO gender & 20378 & 0.956 & 0.206 & 0 & 1 & 1 \\
CEO edu & 16028 & 3.417 & 0.925 & 1 & 4 & 5 \\
\hline \hline
\end{tabular}

Our data sources are the World Development Indicators, Coordinated Direct Investment Survey (CDIS) from IMF, and WGI. The contribution of this paper is the investigation in detail of bilateral data of Chinese FDI to Europe in 39 countries.

Table 3 entails the correlation analysis of variables. The correlation coefficients of all other variables are less than 0.5 except ROA and ROE, which rules out the presence of multicollinearity in our models. Furthermore, the analysis shows a significant negative correlation between CEO_C variables and firm performance proxies, providing preliminary evidence for the research questions being examined in this paper.

Table 4 reports the fixed-effect regression models. The coefficients of overall CEO_Change variables are negative with both ROA and ROE at significance levels of $5 \%$ and $1 \%$, respectively. These results posit that CEO turnover significantly weakens corporate performance. Likewise, the coefficients of CEOchng_1, CEOchng_2 and CEOchng_3 are significantly negative with ROA, and the absolute value of these coefficients increases gradually with an increase in CEO turnover. This indicates that the more frequent the change in leadership is, the more substantive will be the decline in firm performance. Similar conclusions can be drawn from the ROE based regression models. These findings are in line with the notion of organizational theories that the current CEOs are valuable because they have acquired firm-specific knowledge of the competitive environment and enterprise's resources (Castanias and Helfat 1991). Nevertheless, a leadership change would result in the loss of valuable relationships with various stakeholders that the incumbent CEO may have developed overtime (Barney 1986).

We also test the above models in a Two-stage Least Squares (2SLS) based regression environment to overcome the endogeneity issue which might be present in our models. Yet, the prior results remain fundamentally unchanged, which corroborate that the results presented in Table 4 are robust. 
Table 3. Pairwise correlations.

\begin{tabular}{|c|c|c|c|c|c|c|c|c|c|c|c|c|c|}
\hline Variables & (1) & (2) & (3) & (4) & (5) & (6) & (7) & (8) & (9) & (10) & (11) & (12) & (13) \\
\hline (1) $l R O A a$ & 1.000 & & & & & & & & & & & & \\
\hline (2) $l R O E b$ & $0.791 *$ & 1.000 & & & & & & & & & & & \\
\hline (3) CEOchng_all & $-0.060 *$ & $-0.048^{*}$ & 1.000 & & & & & & & & & & \\
\hline (5) CEOchng_2 & $-0.029 *$ & $-0.032 *$ & $0.192 *$ & $-0.018^{*}$ & 1.000 & & & & & & & & \\
\hline (6) CEOchng_3 & -0.007 & -0.003 & $0.047 *$ & 0.006 & $0.049 *$ & 1.000 & & & & & & & \\
\hline (7) Board Size & 0.004 & $0.055^{*}$ & -0.009 & -0.008 & -0.004 & 0.003 & 1.000 & & & & & & \\
\hline (10) Sale growth & 0.001 & 0.005 & 0.001 & 0.001 & 0.001 & -0.000 & 0.001 & 0.007 & -0.002 & 1.000 & & & \\
\hline $\begin{array}{l}\text { (11) Ind Dir } \\
E d u(\%)\end{array}$ & $0.039 *$ & $0.081 *$ & $0.038 *$ & $0.036^{*}$ & $0.014^{*}$ & 0.006 & $-0.047 *$ & $-0.076^{*}$ & $0.059 *$ & -0.008 & 1.000 & & \\
\hline (12) CEOgender & -0.014 & $-0.019^{*}$ & -0.001 & -0.001 & -0.001 & 0.003 & $0.030 *$ & $-0.016^{*}$ & $0.030 *$ & 0.002 & 0.004 & 1.000 & \\
\hline (13) CEOedu & $-0.050^{*}$ & -0.003 & $0.052 *$ & $0.049 *$ & $0.021 *$ & 0.010 & $0.087 *$ & $0.030^{*}$ & $0.161^{*}$ & -0.005 & $0.376^{*}$ & $0.040 *$ & 1.000 \\
\hline
\end{tabular}

$*$ shows significance at the .05 level. The measurements of all variables are explained in Table 1. 
Table 4. Leadership Change and firm performance (Fixed-Effect Regression).

\begin{tabular}{|c|c|c|c|c|c|c|c|c|}
\hline \multirow{2}{*}{$\begin{array}{l}\text { Variables } \\
C E O \_C h a n g e\end{array}$} & \multicolumn{4}{|c|}{ Log of Return on Assets (LROA) } & \multicolumn{4}{|c|}{ Log of Return on Assets (LROE) } \\
\hline & $\begin{array}{r}-0.046^{* *} \\
(0.021)\end{array}$ & & & & $\begin{array}{r}-0.090 * * * \\
(0.025)\end{array}$ & & & \\
\hline CEOchng_l & & $\begin{array}{r}-0.032 * \\
(0.019)\end{array}$ & & & & $\begin{array}{r}-0.056 * * \\
(0.023)\end{array}$ & & \\
\hline CEOchng_2 & & & $\begin{array}{r}-0.274 * * * \\
(0.100)\end{array}$ & & & & $\begin{array}{r}-0.266 * * \\
(0.123)\end{array}$ & \\
\hline CEOchng_3 & & & & $\begin{array}{l}-0.725^{*} \\
(0.439)\end{array}$ & & & & $\begin{array}{r}-0.490 \\
(0.536)\end{array}$ \\
\hline Log Board size & $\begin{array}{l}0.060^{*} \\
(0.031)\end{array}$ & $\begin{array}{r}0.036 \\
(0.029)\end{array}$ & $\begin{array}{l}0.060 * \\
(0.031)\end{array}$ & $\begin{array}{l}0.060^{*} \\
(0.031)\end{array}$ & $\begin{array}{r}0.078 * * \\
(0.038)\end{array}$ & $\begin{array}{r}0.046 \\
(0.035)\end{array}$ & $\begin{array}{r}0.079 * * \\
(0.038)\end{array}$ & $\begin{array}{r}0.079 * * \\
(0.038)\end{array}$ \\
\hline Log Firm size & $\begin{array}{r}0.007 \\
(0.005)\end{array}$ & $\begin{array}{r}0.005 \\
(0.005)\end{array}$ & $\begin{array}{r}0.006 \\
(0.005)\end{array}$ & $\begin{array}{r}0.006 \\
(0.005)\end{array}$ & $\begin{array}{r}0.052 * * * \\
(0.006)\end{array}$ & $\begin{array}{r}0.052 * * * \\
(0.006)\end{array}$ & $\begin{array}{r}0.051^{* * *} \\
(0.006)\end{array}$ & $\begin{array}{r}0.051 * * * \\
(0.006)\end{array}$ \\
\hline Log Firm age & $\begin{array}{r}0.013 \\
(0.019)\end{array}$ & $\begin{array}{r}0.005 \\
(0.018)\end{array}$ & $\begin{array}{r}0.012 \\
(0.019)\end{array}$ & $\begin{array}{r}0.012 \\
(0.019)\end{array}$ & $\begin{array}{r}0.017 \\
(0.023)\end{array}$ & $\begin{array}{r}0.023 \\
(0.022)\end{array}$ & $\begin{array}{r}0.016 \\
(0.023)\end{array}$ & $\begin{array}{r}0.016 \\
(0.023)\end{array}$ \\
\hline Sale growth & $\begin{array}{r}0.000 * * * \\
(0.000)\end{array}$ & $\begin{array}{r}0.000 * * * \\
(0.000)\end{array}$ & $\begin{array}{r}0.000 * * * \\
(0.000)\end{array}$ & $\begin{array}{r}0.000 * * * \\
(0.000)\end{array}$ & $\begin{array}{r}0.000 * * * * \\
(0.000)\end{array}$ & $\begin{array}{l}-0.000 \\
(0.000)\end{array}$ & $\begin{array}{r}0.000 * * * \\
(0.000)\end{array}$ & $\begin{array}{r}0.000 * * * * \\
(0.000)\end{array}$ \\
\hline Ind Dir edu & $\begin{array}{r}0.000 \\
(0.000)\end{array}$ & $\begin{array}{l}0.000^{*} \\
(0.000)\end{array}$ & $\begin{array}{r}0.000 \\
(0.000)\end{array}$ & $\begin{array}{r}0.000 \\
(0.000)\end{array}$ & $\begin{array}{r}0.000 \\
(0.000)\end{array}$ & $\begin{array}{r}0.000 \\
(0.000)\end{array}$ & $\begin{array}{r}0.000 \\
(0.000)\end{array}$ & $\begin{array}{r}0.000 \\
(0.000)\end{array}$ \\
\hline CEO gender & $\begin{array}{c}-0.047^{*} \\
(0.028)\end{array}$ & $\begin{array}{r}-0.054 * * \\
(0.026)\end{array}$ & $\begin{array}{r}-0.047^{*} \\
(0.028)\end{array}$ & & $\begin{array}{l}-0.053 \\
(0.034)\end{array}$ & $\begin{array}{l}-0.052^{*} \\
(0.031)\end{array}$ & $\begin{array}{l}-0.053 \\
(0.034)\end{array}$ & \\
\hline CEO edu & $\begin{array}{r}-0.012 * \\
(0.007)\end{array}$ & & $\begin{array}{r}-0.012^{*} \\
(0.007)\end{array}$ & $\begin{array}{c}-0.012 * \\
(0.007)\end{array}$ & $\begin{array}{r}-0.010 \\
(0.009)\end{array}$ & & $\begin{array}{r}-0.010 \\
(0.009)\end{array}$ & $\begin{array}{r}-0.010 \\
(0.009)\end{array}$ \\
\hline Lag Dep & $\begin{array}{r}0.607 * * * \\
(0.008)\end{array}$ & $\begin{array}{r}0.581 * * * \\
(0.007)\end{array}$ & $\begin{array}{r}0.607 * * * \\
(0.008)\end{array}$ & $\begin{array}{r}0.607 * * * \\
(0.008)\end{array}$ & $\begin{array}{r}0.615 * * * \\
(0.008)\end{array}$ & $\begin{array}{r}0.600 * * * \\
(0.007)\end{array}$ & $\begin{array}{r}0.615^{* * *} * \\
(0.008)\end{array}$ & $\begin{array}{r}0.616^{* * * *} \\
(0.008)\end{array}$ \\
\hline Constant & $\begin{array}{r}-1.526 * * * \\
(0.133)\end{array}$ & $\begin{array}{r}-1.544 * * * \\
(0.122)\end{array}$ & $\begin{array}{r}-1.514 * * * \\
(0.133)\end{array}$ & $\begin{array}{r}-1.548 * * * \\
(0.132)\end{array}$ & $\begin{array}{r}-2.602 * * * \\
(0.163)\end{array}$ & $\begin{array}{r}-2.607 * * * \\
(0.147)\end{array}$ & $\begin{array}{r}-2.581 * * * \\
(0.163)\end{array}$ & $\begin{array}{r}-2.617 * * * \\
(0.161)\end{array}$ \\
\hline Year FE & YES & YES & YES & YES & YES & YES & YES & YES \\
\hline Industry FE & YES & YES & YES & YES & YES & YES & YES & YES \\
\hline Observations & 11,271 & 14,190 & 11,271 & 11,271 & 11,167 & 14,003 & 11,167 & 11,167 \\
\hline$R$-squared & 0.369 & 0.340 & 0.369 & 0.369 & 0.374 & 0.360 & 0.374 & 0.373 \\
\hline
\end{tabular}

Notes: Standard errors in parentheses $* * * \mathrm{p}<0.01, * * \mathrm{p}<0.05, * \mathrm{p}<0.1$

\section{Research conclusions and Implications}

The corporate governance mechanism plays a pivotal role in moderating the principal-agent relationship and safeguarding corporate owners' interests. CEO turnover serves as an essential component of corporate governance mechanism to ensure that managers work in the best interest of shareholders. This study fills a gap in the literature and explores the impact of CEO turnover frequency on corporate performance. Our findings imply that CEO turnover significantly reduces the performance of Chinese listed companies. Moreover, with the increase in turnover frequency, the degree of performance decline gets more substantive. Hence confirms the notion that frequent changes in top leadership are not conducive to an enterprise's economic performance and strategic direction. These findings reveal that corporate power politics is on the rise in Chinese enterprises, adversely influencing their performance. This research also has implications for the board of directors and majority shareholders. First, competent CEO should be hired to avoid frequent changes in corporate leadership. Second, CEOs should be given sufficient tenure to design and implement policies to enhance corporate performance. Third, it is advisable to align firm performance with CEO compensation and minimize the conflict of interests through stock options and performance bonuses than frequent CEO replacements. This research also has some limitations., We do not distinguish between voluntary and forced CEO turnover. Moreover, it would be interesting to examine the impact of CEO turnover on the firm's stock market performance. Future studies can explore this line of research. 
Table 5. Leadership Change and firm performance (2SLS).

\begin{tabular}{|c|c|c|c|c|}
\hline \multirow{2}{*}{$\begin{array}{l}\text { VARIABLES } \\
\text { CEOchng_all }\end{array}$} & \multicolumn{4}{|c|}{ Return on Equity (ROE) } \\
\hline & $\begin{array}{r}-0.477 * * * \\
(0.111)\end{array}$ & & & \\
\hline CEOchng_l & & $\begin{array}{r}-0.182 * * \\
(0.077)\end{array}$ & & \\
\hline CEOchng_2 & & & $\begin{array}{r}-0.491 * * \\
(0.242)\end{array}$ & \\
\hline CEOchng_3 & & & & $\begin{array}{r}-0.544 * * * \\
(0.142)\end{array}$ \\
\hline Log Board size & $\begin{array}{r}-0.755 \\
(0.707)\end{array}$ & $\begin{array}{r}-0.818 \\
(0.798)\end{array}$ & $\begin{array}{r}-0.254 \\
(1.452)\end{array}$ & $\begin{array}{r}-0.512 \\
(1.258)\end{array}$ \\
\hline Log Firm size & $\begin{array}{r}0.610 * * * \\
(0.159)\end{array}$ & $\begin{array}{r}0.687 * * * \\
(0.194)\end{array}$ & $\begin{array}{r}0.068 \\
(0.229)\end{array}$ & $\begin{array}{r}0.046 \\
(0.196)\end{array}$ \\
\hline Log Firm age & $\begin{array}{r}0.949 * * \\
(0.470)\end{array}$ & $\begin{array}{r}1.040^{*} \\
(0.540)\end{array}$ & $\begin{array}{r}0.346 \\
(0.892)\end{array}$ & $\begin{array}{r}0.129 \\
(0.747)\end{array}$ \\
\hline Sale growth & $\begin{array}{r}0.001 * * * * \\
(0.000)\end{array}$ & $\begin{array}{r}0.001 * * \\
(0.000)\end{array}$ & $\begin{array}{r}-0.000 \\
(0.001)\end{array}$ & $\begin{array}{r}0.000 \\
(0.001)\end{array}$ \\
\hline Ind Dir edu & $\begin{array}{r}0.033 * * * \\
(0.009)\end{array}$ & $\begin{array}{r}0.034 * * * \\
(0.010)\end{array}$ & $\begin{array}{l}0.031^{*} \\
(0.018)\end{array}$ & $\begin{array}{r}0.006 \\
(0.009)\end{array}$ \\
\hline CEO gender & $\begin{array}{r}-0.394 \\
(0.613)\end{array}$ & $\begin{array}{r}-0.321 \\
(0.686)\end{array}$ & $\begin{array}{l}-1.308 \\
(1.424)\end{array}$ & \\
\hline CEO edu & $\begin{array}{r}0.013 \\
(0.155)\end{array}$ & & $\begin{array}{r}0.235 \\
(0.354)\end{array}$ & $\begin{array}{r}0.128 \\
(0.289)\end{array}$ \\
\hline Constant & $\begin{array}{r}-12.325 * * * \\
(3.428)\end{array}$ & $\begin{array}{r}-13.549 * * * \\
(4.010)\end{array}$ & $\begin{array}{l}-3.349 \\
(6.432)\end{array}$ & $\begin{array}{r}-4.665 \\
(5.443)\end{array}$ \\
\hline $\begin{array}{l}\text { Year FE } \\
\text { Indutry } F F\end{array}$ & YES & YES & YES & YES \\
\hline Industry FE & YES & YES & YES & YES \\
\hline Observations & 11,167 & 11,167 & 11,167 & 11,167 \\
\hline $\begin{array}{l}R \text {-squared } \\
\text { Under Identification test }\end{array}$ & 0.054 & 0.023 & 0.041 & 0.021 \\
\hline Kleibergen-Paap rk LM statistic & 18.433 & 14.657 & 4.095 & 5.618 \\
\hline $\begin{array}{l}p \text {-value } \\
\text { Week Identification test }\end{array}$ & 0.000 & 0.000 & 0.043 & 0.018 \\
\hline Cragg-Donald Wald F statistics & 13.416 & 14.638 & 4.086 & 5.606 \\
\hline
\end{tabular}

Notes: Standard errors in parentheses $* * * \mathrm{p}<0.01, * * \mathrm{p}<0.05, * \mathrm{p}<0.1$, Stock-Yogo weak ID test critical values: $10 \%$ maximal IV size (16.38)

\section{References}

Akbar, A., Jiang, X., Qureshi, M. A., \& Akbar, M. (2021). Does corporate environmental investment impede financial performance of Chinese enterprises? The moderating role of financial constraints. Environmental Science and Pollution Research, 1-11.

Akbar, A. (2015). The role of corporate governance mechanism in optimizing firm performance: A conceptual model for corporate sector of Pakistan. Journal of Asian Business Strategy, 5(6), 109115.

Akbar, A. (2014). Working capital management and corporate performance: Evidences from textile sector of China. European academic research, 2(9), 11440-11456.

Akbar, M., Akbar, A., \& Draz, M. U. (2021). Global Financial Crisis, Working Capital Management, and Firm Performance: Evidence From an Islamic Market Index. SAGE Open, 11(2), 21582440211015705.

Ballinger, G. A., \& Marcel, J. J. (2010). The use of an interim CEO during succession episodes and firm performance. Strategic Management Journal, 31(3), 262-283.

Barney, J. B. (1986) Organizational culture: can it be a source of sustained competitive advantage?, Academy of management review, 11 (3), 656-665. 
Baum, C. F., Schaffer, M. E. and Stillman, S. (2007) Enhanced routines for instrumental variables/generalized method of moments estimation and testing, The Stata Journal, 7 (4), 465 506.

Bhagat, S. and Bolton, B. (2008) Corporate governance and firm performance, Journal of corporate finance, 14 (3), 257-273.

Boeker, W. (1992). Power and managerial dismissal: Scapegoating at the top. Administrative science quarterly, 400-421.

Castanias, R. P. and C. E. Helfat. (1991) Managerial resources and rents, Journal of management, 17 (1), 155-171.

Chang, E. C. and Wong, S. M. (2004) Chief executive officer turnovers and the performance of China's listed enterprises, Hong Kong Institute of Economics and Business Strategy, Working Paper (1113).

Conyon, M. and He, L. (2008) CEO Turnover and Firm Performance in China's Listed Firms (CRI 2009-012).

Conyon, M. J. and He, L. (2011) Executive compensation and corporate governance in China, Journal of Corporate Finance, 17 (4), 1158-1175.

Dalton, D. R. and Todor, W. D. (1979) Turnover turned over: An expanded and positive perspective, Academy of management review, 4 (2), 225-235.

de Mesquita Ferreira, L. C. and de Aquino Almeida, C. B. (2015) Employee turnover and organizational performance: A study of the Brazilian retail sector, Brazilian Business Review, 12 (4), 27-56.

Firth, M., Fung, P. M. and Rui, O. M. (2006) Firm performance, governance structure, and top management turnover in a transitional economy, Journal of Management Studies, 43 (6), 12891330.

Haveman, H. A., Russo, M. V., \& Meyer, A. D. (2001). Organizational environments in flux: The impact of regulatory punctuations on organizational domains, CEO succession, and performance. Organization science, 12(3), 253-273.

Jensen, M. C. and Meckling, W. H. (1976) Theory of the firm: Managerial behavior, agency costs and ownership structure, Journal of financial economics, 3 (4), 305-360.

Kesner, I. F., \& Sebora, T. C. (1994). Executive succession: Past, present \& future. Journal of management, 20(2), 327-372.

Kim, Y., Jeong, S. S., Yiu, D. W., \& Moon, J. (2020). Frequent CEO turnover and firm performance: The resilience effect of workforce diversity. Journal of Business Ethics, 1-19.

Pencavel, J. H. (1972) Wages, specific training, and labor turnover in US manufacturing industries, International Economic Review, 53-64.

Quigley, T. J., \& Hambrick, D. C. (2015). Has the "CEO effect" increased in recent decades? A new explanation for the great rise in America's attention to corporate leaders. Strategic Management Journal, 36(6), 821-830.

Qureshi, M. A., Akbar, M., Akbar, A., \& Poulova, P. (2021). Do ESG Endeavors Assist Firms in Achieving Superior Financial Performance? A Case of 100 Best Corporate Citizens. SAGE Open, 11(2), 21582440211021598.

Salancik, G. R., \& Pfeffer, J. (1980). Effects of ownership and performance on executive tenure in US corporations. Academy of Management journal, 23(4), 653-664.

Schepker, D. J., Kim, Y., Patel, P. C., Thatcher, S. M., \& Campion, M. C. (2017). CEO succession, strategic change, and post-succession performance: A meta-analysis. The Leadership Quarterly, 28(6), 701-720.

Shen, W., \& Cho, T. S. (2005). Exploring involuntary executive turnover through a managerial discretion framework. Academy of Management Review, 30(4), 843-854.

Wang, Z., Akbar, M., \& Akbar, A. (2020). The interplay between working capital management and a firm's financial performance across the corporate life cycle. Sustainability, 12(4), 1661.

Wooldridge, J. M. (2010) Econometric analysis of cross section and panel data, MIT Press: Cambridge. 